JURNAL 『E⿷KRNOSAINS

VOLUME 1

No. 1, 22 Desember 2011

Halaman 1-69

\title{
ANALISIS POTENSI ENERGI DI DESA WUKIRSARI KECAMATAN IMOGIRI KABUPATEN BANTUL PROPINSI DAERAH ISTIMEWA YOGYAKARTA
}

\author{
Dhanis Woro Fittrin Selo Nur Giyatno \\ Mahasiswa Jurusan Teknik Fisika Fakultas Teknik Universitas Gadjah Mada \\ Email: danisfittrin@yahoo.com
}

\begin{abstract}
Dengkeng, Kobango, Giriloyo, and Nogosari II are places in the Wukirsari village which experience water scarcity. Water supply system (WSS) is proposed to fulfill water for 1,088 persons. The WSS need energy for pumping amount $88.47 \mathrm{kWh}$ per day. Based on Atmospheric Data Science's datas, obtained that the average of wind velocity in Imogiri is 4.20 meters/second and 50.00 meters in height above the sea level. The standard of wind velocity to build wind power generation is must more than 3.00 meter/second so enable to design in another turbine height. By region coefficient (a) 0.30, is obtained turbine height alternative $18.17-50.00$ meters in range. By varied wind velocity base on that range obtained wind velocity average amount 3.70 meters/second and 32.17 - 33.17 meters in height range. Based on WSS's lifetime and wind specific mass, obtained power per wide unit $21.06 \mathrm{~W} / \mathrm{m}^{2}$ and energy $0.02 \mathrm{kWh} / \mathrm{m}^{2}$ each day.
\end{abstract}

Keywords: Wukirsari, water, wind, energy, turbine

\begin{abstract}
ABSTRAK
Dusun Dengkeng, Kobango, Giriloyo, dan Nogosari II adalah daerah yang terletak di Desa Wukirsari yang mengalami kelangkaan air minum. Sistem Penyediaan Air Minum (SPAM) ditujukan untuk memenuhi kebutuhan air minum untuk 1.088 jiwa. Energi yang dibutuhkan untuk memompa air pada instalasi SPAM adalah 88,47 kWh/hari. Berdasarkan data kecepatan angin dari Atmospheric Data Science, diperoleh rata-rata kecepatan angin 4,20 meter/detik pada ketinggian 50,00 meter di atas permukaan air laut. Standar kelayakan kecepatan angin untuk membangun pembangkit listrik tenaga angin adalah lebih dari 3,00 meter/detik sehingga memungkinkan untuk merancang ketinggian pemanfaatan angin pada ketinggian lain. Dengan koefisien wilayah ( ) 0,30 maka diperoleh alternatif ketinggian pemanfaatan angin pada 18,17-50,00 meter. Dengan memvariasikan kecepatan angin pada jangkauan tersebut diperoleh rata-rata kecepatan angin optimal 3,70 meter/detik pada ketinggian sekitar 32,1733,17 meter. Berdasarkan usia pakai SPAM dan massa jenis udara setempat diperoleh daya per luasan $21,06 \mathrm{~W} / \mathrm{m}^{2}$ dan energi $0,02 \mathrm{kWh} / \mathrm{m}^{2}$ per hari.
\end{abstract}

Kata kunci: Wukirsari, air, angin, energi, turbin 


\section{PENGANTAR}

Dusun Dengkeng, Kobango, Giriloyo, dan Nogosari II merupakan bagian dari Desa Wukirsari, Kecamatan Imogiri, Kabupaten Bantul, Propinsi Daerah Istimewa Yogyakarta yang mengalami kelangkaan air minum dan atau air bersih. Secara astronomis, Desa Wukirsari terletak di $7^{\circ} 54^{\prime} 30^{\prime \prime}$ LS dan $110^{\circ} 23^{\prime} 06^{\prime \prime}$ BT (Anonim, 2009). Sedangkan secara geografis, Desa Wukirsari dibatasi sebagai berikut:

$\begin{array}{lll}\text { utara } \quad: \quad \begin{array}{l}\text { Wonolelo, Bauran, } \\ \text { Segoroyoso (Kecamatan } \\ \end{array} & \begin{array}{l}\text { Pleret), Trimurti (Kecamatan } \\ \text { Jetis) }\end{array} \\ \text { barat } \quad: \quad \begin{array}{l}\text { Trimurti, Sumberagung } \\ \text { (Kecamatan Jetis) }\end{array} \\ \text { selatan } \quad: \quad \begin{array}{l}\text { Imogiri, Girirejo (Kecamatan } \\ \text { Imogiri) }\end{array} \\ \text { timur } \quad: \quad \text { Muntuk (Kecamatan Dlingo) }\end{array}$

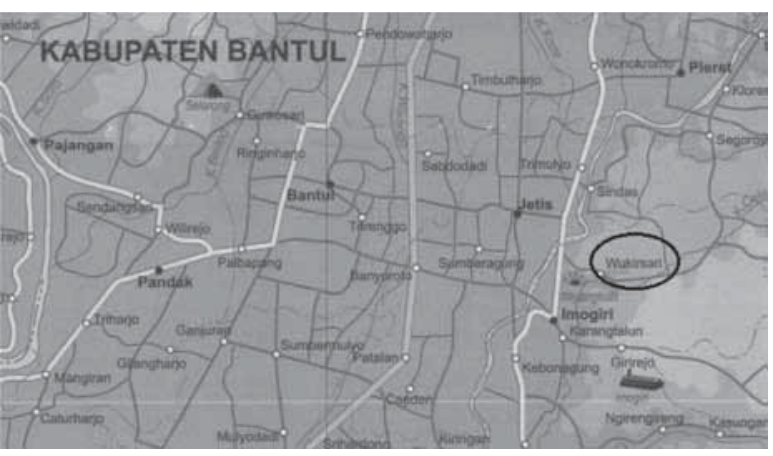

Gambar 1.

Dusun Dengkeng, Kobango, Nogosari II, dan Giriloyo merupakan desa yang terletak di Desa Wukirsari yang menjadi sasaran daerah layanan SPAM. Dalam peta ini, Dusun Kobango belum tercantum.

Untuk memenuhi kebutuhan air minum, masyarakat harus melakukan dropping air atau membeli air dari pedagang jerigen keliling. Dengan harga air bersih $\mathrm{Rp}$ $26.500,00 / \mathrm{m}^{3}$, setiap kepala keluarga (KK) harus mengeluarkan Rp 338.000,00/bulan. Di sisi lain, pendapatan warga Desa Wukirsari adalah sekitar Rp 500.000,00/bulan/KK.
Dengan demikian, secara tidak langsung, kelangkaan air bersih telah mengakibatkan kemiskinan. Hal tersebut ditunjukkan oleh persentase jumlah penerima Bantuan Langsung Tunai (BLT) (Data Dinas Sosial Bantul, 2010).

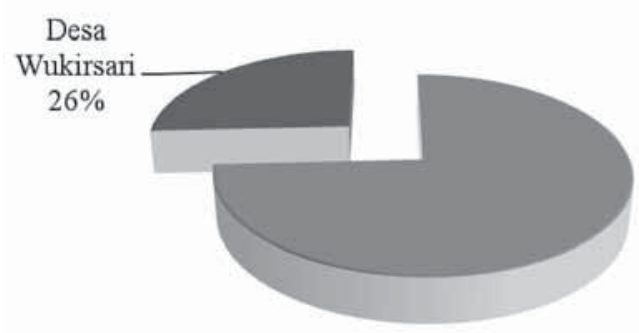

Gambar 2.

Persentase penerima BLT tahun 2009 di Desa Wukirsari (Dinas Sosial Kabupaten Bantul, 2010)

Sistem penyediaan air minum yang dibangun di Desa Wukirsari ditujukan untuk menanggulangi masalah kelangkaan air. Penyelenggaraan sistem penyediaan air minum dilaksanakan berdasarkan Peraturan Menteri Pekerjaan Umum Nomor: 18/ PRT/M/2007 tentang Penyelenggaraan Pengembangan Sistem Penyediaan Air Minum (Menteri Pekerjaan Umum, 2007) dan Peraturan Pemerintah Republik Indonesia Nomor 16 Tahun 2005 tentang Pengembangan Sistem Penyediaan Air Minum (Pemerintah Republik Indonesia, Maret: 2010) Sistem Penyediaan Air Minum (SPAM) ditujukan untuk memenuhi kebutuhan air bersih di daerah tersebut selama 25 tahun, yaitu 2010 - 2035 untuk 1.088 jiwa (Dhanis Woro, 2010). 


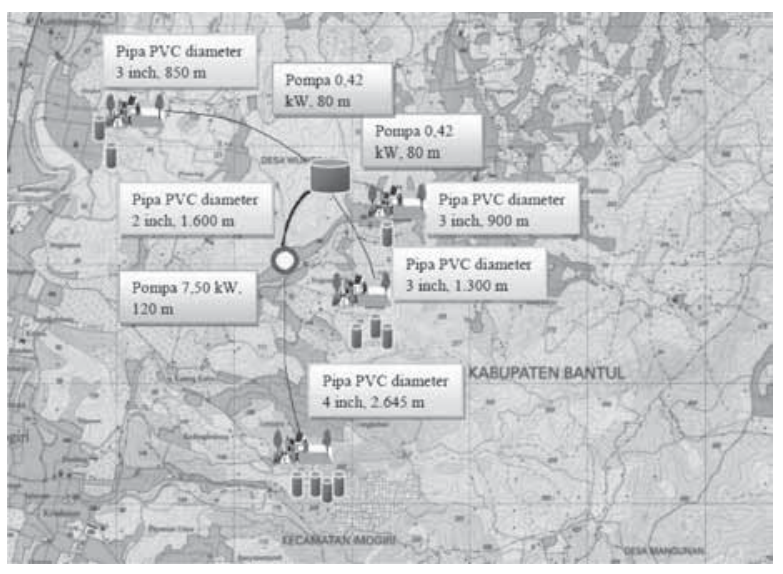

Gambar 3.

Desain teknis SPAM Desa Wukirsari

SPAM Desa Wukirsari menggunakan sumber air berupa air tanah dalam sehingga dibutuhkan sumber ketenagaan untuk memompa air.

Tabel 1.

Energi harian sistem pemompaan SPAM

Desa Wukirsari

\begin{tabular}{|llll|}
\hline \multicolumn{1}{|c}{ Jenis } & \multicolumn{1}{c}{ Daya } \\
pompa & $\begin{array}{c}\text { Daya } \\
\text { mula }(\mathrm{kW})\end{array}$ & $\begin{array}{c}\text { Energi } \\
\text { total } \\
(\mathrm{kW})\end{array}$ & $\begin{array}{c}\text { harian } \\
(\mathrm{kWh}) \\
\mathrm{DC}\end{array}$ \\
\hline $\begin{array}{l}\text { Pompa } \\
\text { penyadap }\end{array}$ & 6,08 & 6,08 & 86,99 \\
\hline $\begin{array}{l}\text { Pompa } \\
\text { distribusi }\end{array}$ & 0,20 & 0,60 & 1,48 \\
\hline Jumlah & & 6,68 & 88,47 \\
\hline
\end{tabular}

Sumber: Dhanis Woro Fittrin Selo Nur Giyatno, 2010.

Menurut Scremph (2000), masalah utama manusia adalah ketersediaan energi. Minyak bumi akan habis dalam jangka waktu 10 sampai 15 tahun ke depan. Setelah itu, akan ditemui beberapa masalah terkait dengan energi terutama di negara-negara berkembang (Basam Nassir El dan Maegaard Preben, 2004)
Tabel 2.

Potensi energi fosil tahun 2008

\begin{tabular}{|lllll|}
\hline \multicolumn{1}{|c}{$\begin{array}{c}\text { Energi } \\
\text { fosil }\end{array}$} & $\begin{array}{l}\text { Sumber } \\
\text { daya }\end{array}$ & Cadangan & Produksi & $\begin{array}{c}\text { Rasio } \\
\text { cadangan }\end{array}$ \\
\hline $\begin{array}{l}\text { Minyak } \\
\text { bumi }\end{array}$ & $\begin{array}{l}56,6 \\
\text { Miliar } \\
\text { bare }\end{array}$ & $\begin{array}{l}8,2 \\
\text { miliar } \\
\text { ton }\end{array}$ & $\begin{array}{l}\text { 357 juta } \\
\text { barel }\end{array}$ & 23 \\
\hline $\begin{array}{l}\text { Gas } \\
\text { bumi }\end{array}$ & $\begin{array}{l}334,5 \\
\text { TSCF }\end{array}$ & $\begin{array}{l}170 \\
\text { TSCF }\end{array}$ & 2,7 TSCF & 63 \\
\hline $\begin{array}{l}\text { Batu } \\
\text { bara }\end{array}$ & $\begin{array}{l}104,8 \\
\text { miliar } \\
\text { ton }\end{array}$ & $\begin{array}{l}\text { 18,8 } \\
\text { miliar } \\
\text { ton }\end{array}$ & $\begin{array}{l}229,2 \text { juta } \\
\text { ton }\end{array}$ & 82 \\
\hline $\begin{array}{l}\text { Coal Bed } \\
\text { Methane } \\
\text { (CBM) }\end{array}$ & $\begin{array}{l}453 \\
\text { TSCF }\end{array}$ & - & - & - \\
\hline
\end{tabular}

Sumber: Presiden Republik Indonesia, 2010.

Tabel 3.

Perkembangan subsidi serta biaya bahan bakar dan pelumas

\begin{tabular}{|lll|}
\hline Tahun & $\begin{array}{c}\text { Subsidi } \\
\text { (Rp. } \\
\text { Triliun) }\end{array}$ & $\begin{array}{c}\text { Biaya bahan bakar dan } \\
\text { pelumas (Rp. Triliun) }\end{array}$ \\
\hline 2004 & 3,47 & 24,49 \\
\hline 2005 & 12,51 & 37,36 \\
\hline 2006 & 32,91 & 63,40 \\
\hline 2007 & 36,60 & 65,56 \\
\hline 2008 & 78,58 & 107,78 \\
\hline
\end{tabular}

Sumber: Presiden Republik Indonesia, 2010.

Untuk memenuhi kebutuhan energi minyak bumi di dalam negeri, Pemerintah melakukan impor meskipun harga minyak di pasar internasional terus melonjak. Kondisi ini membebani Anggaran Pendapatan Belanja Negara (APBN). Oleh karena itu, pemerintah mulai mencari cara untuk menggantikan minyak fosil (BBM) ke energi alternatif atau energi terbarukan yang berasal dari bahan bakar nabati dan non-nabati (Anonim,2009).

Menurut Bruntland Report (1987), pembangunan berkelanjutan adalah proses pembangunan (lahan, kota, bisnis, masyarakat, dan lain sebagainya) yang berprinsip "memenuhi kebutuhan sekarang tanpa mengorbankan pemenuhan kebutuhan generasi masa depan" (Dewan Redaksi, 2010). Salah satu dimensi dalam pembangunan berkelanjutan adalah dimensi ekologi. Masalah utama pada dimensi ekologi adalah 


\section{DHANIS WORO FITTRIN SELO NUR GIYATNO ANALISIS POTENSI ENERGI DI DESA WUKIRSARI, KECAMATAN IMOGIRI, KABUPATEN BANTUL, PROPINSI ...}

pemanasan global yang disebabkan oleh emisi gas rumah kaca (GRK) dari aktivitas manusia (Supriyono dan Subejo, 2010). Pemanfaatan minyak bumi dalam bentuk solar akan memproduksi polutan. Polutan terbesar dari pembakaran bahan bakar fosil adalah emisi $\mathrm{CO}_{2}, \mathrm{SO}_{2}, \mathrm{NO}_{x^{\prime}}$ partikel, dan debu pengotor. Emisi $\mathrm{CO}_{2}$ bisa berdampak pada pemanasan global, sedang emisi $\mathrm{SO}_{2}$ dan $\mathrm{NO}_{x}$ berpotensi menimbulkan hujan asam. Sementara partikel dan debu pengotor dapat mengakibatkan polusi udara yang bisa berdampak serius pada kesehatan manusia (Djati dkk.,2010).

Selain dalam hal ekologi, konsep sustainable development perlu diterapkan dalam bangunan, yaitu pembangkit listrik tenaga angin (PLT Angin) yang memenuhi sustainable building. Tujuan diterapkannya kebijaksanaan tentang sustainable building sebagai berikut: (1) Menyelematkan manusia dan lingkungan dari bahaya yang dihadapinya; Menunjukkan komitmen perdesaan terhadap lingkungan, ekonomi, dan pelayanan sosial; (3) Menghasilkan penghematan dana bagi pembangunan; (4) Menyediakan lingkungan kerja yang sehat bagi masyarakat; dan (5) Mempercepat pencapaian tujuan perdesaan dalam melindungi, mengkonservasi, dan meningkatkan sumber-sumber lingkungan di daerah (Yulesta Putra, 2004).

Oleh karena itu, diperlukan sumber energi untuk menyediakan kebutuhan energi untuk sistem pemompaan yang ramah lingkungan dan tersedia dengan tidak terbatas. Energi angin merupakan salah satu jenis energi yang sesuai untuk menyediakan kebutuhan energi di daerah terpencil yang memenuhi prinsip sustainability development adalah energi angin (Maria Retnanestri, 2009).

Berdasarkan letak astronomisnya, Indonesia termasuk negara yang terletak di daerah tropis. Dengan demikian, secara umum Desa Wukirsari berpotensi untuk menghasilkan energi angin. Pembangkitan energi angin layak dilakukan di suatu lokasi jika mempunyai rata-rata kecepatan angin lebih dari 3 meter/detik (Farret A Felix,
2002). Di sisi lain, kecepatan angin tergantung dengan ketinggian dan koefisien kondisi wilayah ( ). Hubungan antara ketinggian dengan kecepatan angin dan faktor wilayah (Andhy, 2008)

$$
\frac{v_{2}}{v_{1}}=\left(\frac{h_{2}}{h_{1}}\right)^{\alpha}
$$

$$
\begin{array}{lll}
\mathrm{v}_{1}: & \begin{array}{l}
\text { Kecepatan angin di ketinggian } \mathrm{h}_{1} \\
(\mathrm{~m} / \mathrm{s})
\end{array} \\
\mathrm{v}_{2}: & \begin{array}{l}
\text { Ketinggian angin di ketinggian } \mathrm{h}_{2} \\
(\mathrm{~m} / \mathrm{s})
\end{array} \\
\mathrm{h}_{1}: & \text { Ketinggian awal (meter) } \\
\mathrm{h}_{2}: & \text { Ketinggian desain (meter) } \\
\alpha & : & \begin{array}{l}
\text { Koefisien kondisi wilayah }(=0,30, \\
\text { untuk daerah perbukitan dan } \\
\text { pepohonan (Fathoni, 2008) }
\end{array} \\
&
\end{array}
$$

Densitas daya yang dihasilkan oleh energi angin mempunyai range yang sangat lebar. Hal tersebut merupakan tantangan dalam pemilihan kecepatan kerja angin dan konstruksi generator daya angin (Bassam Nasir El dan Maegaard, 2004).

Untuk menentukan daya yang dihasilkan oleh gerakan angin, maka dapat digunakan rumus sebagai berikut:

$$
P=1 / 2 C_{p} \rho A v^{3}
$$

$$
\begin{array}{lll}
\mathrm{P} & : & \text { Daya terotik yang dihasilkan }(\mathrm{W}) \\
\mathrm{C}_{\mathrm{p}} & : & \text { Koefisien daya teoritik }(=0,593) \\
\rho & : & \text { Densitas udara }\left(\mathrm{kg} / \mathrm{m}^{3}\right) \\
\mathrm{A} & : & \begin{array}{l}
\text { Luas rotor yang digerakkan oleh } \\
\text { angin }\left(\mathrm{m}^{2}\right)
\end{array} \\
\mathrm{v} & : & \text { Kecepatan angin (meter/detik) }
\end{array}
$$

Dengan demikian, jumlah energi yang dihasilkan oleh angin adalah :

$$
\mathrm{W}=\text { P.t }
$$

W : Energi yang dihasilkan (Wh)

P : Daya yang dihasilkan (W)

t : Waktu kerja (jam) 
Pada suhu $25^{\circ} \mathrm{C}$, kecepatan angin di Desa Wukirsari adalah sebagai berikut.

Tabel 4.

Kecepatan angin di Kecamatan Imogiri, Kabupaten Bantul

Propinsi Daerah Istimewa Yogyakarta

\begin{tabular}{|c|c|c|c|}
\hline No. & Bulan & $\begin{array}{c}\text { Temperatur } \\
\text { udara }\left({ }^{\circ} \mathrm{C}\right)\end{array}$ & $\begin{array}{c}\text { Kecepatan } \\
\text { angin pada } \\
\text { ketinggian } \\
50 \text { meter } \\
\text { (meter/detik) }\end{array}$ \\
\hline 1. & Januari & 25,10 & 3,73 \\
\hline 2. & Februari & 25,10 & 3,92 \\
\hline 3. & Maret & 25,30 & 2,89 \\
\hline 4. & April & 25,30 & 3,29 \\
\hline 5. & Mei & 25,00 & 4,51 \\
\hline 6. & Juni & 24,50 & 5,13 \\
\hline 7. & Juli & 24,20 & 5,80 \\
\hline 8. & Agustus & 24,50 & 5,91 \\
\hline 9. & September & 25,00 & 5,13 \\
\hline 10. & Oktober & 25,40 & 3,97 \\
\hline 11. & November & 25,20 & 3,30 \\
\hline 12. & Desember & 25,00 & 2,86 \\
\hline Rata & ata & 25,00 & 4,20 \\
\hline
\end{tabular}

Sumber : Atmospheric Data Science Center, 2010

Kecepatan angin yang layak untuk dimanfaatkan sebagai energi listrik melalui pembangkitan listrik tenaga angin adalah lebih dari 3,00 meter/detik atau 3,10 meter/ detik. Sementara itu, kecepatan angin di suatu wilayah tergantung oleh kondisi wilayah dan ketinggian pemanfaatannya. Rata-rata kecepatan angin pada ketinggian 50 meter adalah 4,20 meter/detik (Atmospheric Science Data Center, 2010). Hal tersebut memungkinkan untuk merancang ketinggian pemanfaatan kecepatan angin dari ketinggian $h_{2}$. Nilai $h_{2}$ dapat ditentukan dengan perumusan sebagai berikut.

$$
\log \mathrm{h}_{2}=\left(\log \mathrm{v}_{2}-\log \mathrm{v}_{1}\right) / \alpha+\log \mathrm{h}_{1}
$$

dengan $\alpha=0,30$ sehingga dihasilkan $h_{2}=18,17$ meter.
Dengan demikian, rentang ketinggian pemanfaatan energi angin adalah dengan turbin dengan ketinggian rotor 18,17 - 50,00 meter. Dengan memvariasikan kecepatan angin berdasarkan nilai $h_{2}$ pada rentang tersebut, diperoleh nilai rata-rata kecepatan angin 3,699055 meter/detik. Nilai tersebut berada pada rentang ketinggian 32,17 - 33,17 meter.

Berdasarkan grafik persentase ketersediaan kecepatan angin, kecepatan angin sebesar 3,699055 meter/detik tersedia dalam persentase paling tinggi $(85 \%)$ setiap tahun. Meskipun demikian, tidak berarti bahwa tidak ada kecepatan angin yang terjadi pada kurun waktu tersebut. Dengan demikian, perhitungan potensi energi angin digunakan persentase ketersediaan angin $100 \%$.

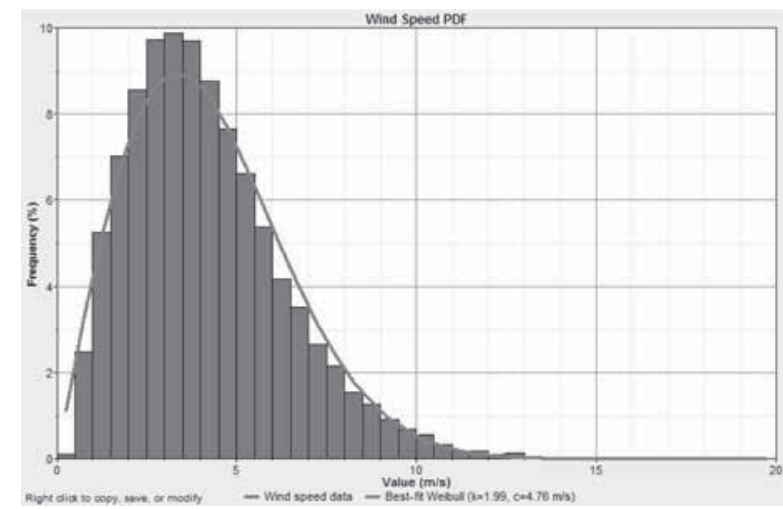

Gambar 4.

Persentase ketersediaan kecepatan angin dengan software HOMER

Tabel 5.

Analisis kecepatan angin pada variasi ketinggian lokasi di Desa Wukirsari, Kecamatan Imogiri, Kabupaten Bantul, Propinsi Daerah Istimewa Yogyakarta

\begin{tabular}{|ccccc|}
\hline $\begin{array}{c}\mathrm{h}_{1} \\
\text { (meter) }\end{array}$ & $\begin{array}{c}\mathrm{h}_{2} \\
\text { (meter) }\end{array}$ & $\begin{array}{c}\mathrm{v}_{1} \\
\text { (meter/ } \\
\text { detik) }\end{array}$ & $\alpha$ & $\begin{array}{c}\mathrm{v}_{2} \text { (meter/ } \\
\text { detik) }\end{array}$ \\
\hline 50,00 & 18,17 & 4,20 & 0,30 & 3,100022 \\
\hline 50,00 & 19,17 & 4,20 & 0,30 & 3,150249 \\
\hline 50,00 & 20,17 & 4,20 & 0,30 & 3,198675 \\
\hline 50,00 & 21,17 & 4,20 & 0,30 & 3,245447 \\
\hline 50,00 & 22,17 & 4,20 & 0,30 & 3,290698 \\
\hline
\end{tabular}




\begin{tabular}{|lllll|}
\hline 50,00 & 23,17 & 4,20 & 0,30 & 3,334541 \\
\hline 50,00 & 24,17 & 4,20 & 0,30 & 3,377079 \\
\hline 50,00 & 25,17 & 4,20 & 0,30 & 3,418403 \\
\hline 50,00 & 26,17 & 4,20 & 0,30 & 3,458593 \\
\hline 50,00 & 27,17 & 4,20 & 0,30 & 3,497721 \\
\hline 50,00 & 28,17 & 4,20 & 0,30 & 3,535854 \\
\hline 50,00 & 29,17 & 4,20 & 0,30 & 3,573051 \\
\hline 50,00 & 30,17 & 4,20 & 0,30 & 3,609366 \\
\hline 50,00 & 31,17 & 4,20 & 0,30 & 3,644847 \\
\hline 50,00 & 32,17 & 4,20 & 0,30 & 3,679541 \\
\hline 50,00 & 33,17 & 4,20 & 0,30 & 3,713487 \\
\hline 50,00 & 34,17 & 4,20 & 0,30 & 3,746725 \\
\hline 50,00 & 35,17 & 4,20 & 0,30 & 3,779288 \\
\hline 50,00 & 36,17 & 4,20 & 0,30 & 3,811210 \\
\hline 50,00 & 37,17 & 4,20 & 0,30 & 3,842519 \\
\hline 50,00 & 38,17 & 4,20 & 0,30 & 3,873245 \\
\hline 50,00 & 39,17 & 4,20 & 0,30 & 3,903412 \\
\hline 50,00 & 40,17 & 4,20 & 0,30 & 3,933044 \\
\hline 50,00 & 41,17 & 4,20 & 0,30 & 3,962165 \\
\hline 50,00 & 42,17 & 4,20 & 0,30 & 3,990795 \\
\hline 50,00 & 43,17 & 4,20 & 0,30 & 4,018953 \\
\hline 50,00 & 44,17 & 4,20 & 0,30 & 4,046658 \\
\hline 50,00 & 45,17 & 4,20 & 0,30 & 4,073928 \\
\hline 50,00 & 46,17 & 4,20 & 0,30 & 4,100778 \\
\hline 50,00 & 47,17 & 4,20 & 0,30 & 4,127224 \\
\hline 50,00 & 48,17 & 4,20 & 0,30 & 4,153281 \\
\hline 50,00 & 49,17 & 4,20 & 0,30 & 4,178961 \\
\hline Rata-rata & & & 3,699055 \\
\hline & & & & \\
\hline
\end{tabular}

Berdasarkan nilai tersebut maka energi yang dihasilkan oleh kecepatan angin pada 32,17 meter $<\mathrm{h}_{2}<33,17$ meter dapat ditentukan sebagai berikut:

$$
\begin{array}{ll}
\mathrm{v} & =3,699055 \text { meter } / \text { detik } \\
\mathrm{t}_{2}-\mathrm{t}_{1} & =25 \text { tahun } \\
\rho & =1,4034 \mathrm{~kg} / \mathrm{m}^{3}
\end{array}
$$

Dengan demikian, daya per-satuan luas yang dihasilkan oleh kecepatan angin 3,699055 meter/detik adalah sebagai berikut:

$$
\begin{aligned}
\mathrm{P} / \mathrm{A}= & {\left[1 / 2 \times 0,593 \times 1,4034 \mathrm{~kg} / \mathrm{m}^{3} \times \mathrm{A} \times\right.} \\
& \left.(3,699055 \text { meter } / \text { detik })^{3}\right] / \mathrm{A} \\
= & 21,06 \mathrm{~W} / \mathrm{m}^{2}
\end{aligned}
$$

Selama usia pakai SPAM, yaitu 25 tahun, energi angin yang tersedia pada ketinggian $\mathrm{h}_{2}$ adalah sebagai berikut:

$$
\begin{aligned}
\mathrm{W} & =21,06 \mathrm{~W} / \mathrm{m}^{2} \times 25 \text { tahun } \times 365 \\
& =184.485,60 \mathrm{~W} / \mathrm{m}^{2} \\
& =184,49 \mathrm{kWh} / \mathrm{m}^{2} \\
& =0,02 \mathrm{kWh} / \mathrm{m}^{2} \text { per hari }
\end{aligned}
$$

Dengan demikian, jika diperlukan 88,47 kWh per hari, maka diperlukan luas sapuan rotor sebesar $4.423,50 \mathrm{~m}^{2}$.

\section{PEMBAHASAN}

Energi angin adalah salah satu jenis energi terbarukan yang disarankan oleh Maria Retnanestri (2009) untuk menyelenggarakan pembangunan berkelanjutan (sustainability development) di daerah perdesaan. Selain karena energi angin bersumber pada sumber daya alam yang tak terbatas, pemanfaatan energi angin dapat mengurangi polutan di udara.

Tabel 6.

Laju emisi pemanfaatan bahan bakar fosil ${ }^{*}$

\begin{tabular}{|lll|}
\hline No. & \multicolumn{1}{c}{ Polutan } & \multicolumn{1}{c|}{$\mathrm{EF}(\mathrm{kg} / \mathrm{kWh})$} \\
\hline 1. & $\mathrm{PM}_{10}$ & $4,38 \times 10^{-4}$ \\
\hline 2. & $\mathrm{NO}_{x}$ & $6,69 \times 10^{-3}$ \\
\hline 3. & $\mathrm{SO}_{x}$ & $3,59 \times 10^{-4}$ \\
\hline 4. & $\mathrm{CO}$ & $2,67 \times 10^{-1}$ \\
\hline 5. & $\mathrm{CO}_{2}$ & $6,56 \times 10^{-1}$ \\
\hline *: Bahan bakar fosil untuk menggerakkan genset \\
Sumber: Deputi Bidang Tata Lingkungan, 2007.
\end{tabular}

Dengan kondisi seperti di atas, maka dengan menggantikan genset yang biasanya digunakan untuk memompa air pada SPAM dengan pembangkit listrik tenaga angin, dapat dikurangi emisi sebesar:

$$
\begin{aligned}
\text { Reduksi }= & 88,47 \mathrm{kWh} \times\left(4,38 \times 10^{-4}+6,69\right. \\
\text { emisi } & \times 10^{-3}+3,59 \times 10^{-4}+2,67 \times 10^{-1}+ \\
& \left.6,56 \times 10^{-1}\right) \mathrm{kh} / \mathrm{kWh} \\
= & 82,28 \mathrm{~kg}
\end{aligned}
$$

Pemanfaatan energi angin dalam pembangkit listrik tenaga angin di Indonesia menemui beberapa masalah. Beberapa di antaranya adalah terkait dengan posisi Indonesia yang terletak di daerah rawan gempa dan kebutuhan ruang untuk pemukiman.

Kepulauan Indonesia merupakan salah satu wilayah tektonik dan volkanik yang paling efektif di dunia. Oleh karena itu, 
kerawanan tsunami seperti halnya bencana alam gempa dan letusan gunung api akan selalu terjadi di wilayah kepulauan Indonesia. Evaluasi likuifaksi di Kabupaten Bantul berdasarkan peta zonasi seismik tahun 19001999 menyatakan bahwa Kabupaten Bantul, dalam hal ini termasuk Kecamatan Imogiri di dalamnya termasuk dalam zona 3 dengan percepatan gempa (g) 0,8 - 1,2 dengan magnitudo gempa 6 - 6,5 SR untuk periode ulang 20 tahun. Kerawanan tsunami dapat menimbulkan dampak negatif terhadap pembangunan infrastruktur, dalam hal ini turbin angin pada pembangkit listrik tenaga angin (PLT Angin). Upaya pembangunan infrastruktur terutama di kawasan rawan tsunami diperlukan pengaturan dan perencanaan umum serta manajemen yang menyeluruh, terpadu, serasi, dan seimbang dengan memperlihatkan kebutuhan generasi sekarang dan akan datang sehingga menjamin infrastruktur dapat berfungsi dengan baik dan aman (Data dari Departemen Pekerjaan Umum, 2009).

Daerah rencana pembangunan PLT Angin termasuk kawasan perdesaan. Menurut Undang-undang Republik Indonesia Nomor 26 Tahun 2007 tentang Penataan Ruang Pasal 1 ayat 23, kawasan perdesaan adalah wilayah yang mempunyai kegiatan utama pertanian, termasuk pengelolaan sumber daya alam dengan susunan kawasan sebagai tempat permukiman perdesaan, pelayanan jasa pemerintahan, pelayanan sosial, dan kegiatan ekonomi. Dalam Pasal 3 disebutkan bahwa penyelenggaraan penataan ruang bertujuan untuk mewujudkan ruang wilayah nasional yang aman, nyaman, produktif, dan keberlanjutan berdasarkan Wawasan Nusantara dan Ketahanan Nasional dengan sebagai berikut:

a. Terwujudnya keharmonisan antara lingkungan alam dan lingkungan buatan;

b. Terwujudnya keterpaduan dalam penggunaan sumber dayaalam dansumber daya buatan dengan memperhatikan sumber daya manusia; dan c. Terwujudnya pelindungan fungsi ruang dan pencegahan dampak negatif terhadap akibat pemanfaatan ruang (Data dari Departemen Pekerjaan Umum, 2007).

Selain terkait dengan masalah posisi Indonesia yang rawan bencana gempa dan tsunami dan kebutuhan lahan untuk pemukiman, masalah-masalah yang terkait dengan faktor pencapaian sustainable building perlu dipertimbangkan sebelum membangun PLT Angin, yaitu faktor sosial, ekonomi, dan lingkungan dalam studi pra-kelayakan pembangunan PLT Angin.

\section{SIMPULAN}

Potensi energi angin di Kecamatan Imogiri, Kabupaten Bantul, Propinsi Daerah Istimewa Yogyakarta adalah 0,02 kWh/ $\mathrm{m}^{2}$ per hari. Untuk memenuhi kebutuhan energi untuk memompa air ke pemukiman warga sebesar $88,47 \mathrm{kWh}$ per hari diperlukan luas sapuan rotor sebesar 4.423,50 $\mathrm{m}^{2}$. Akan tetapi, untuk membangun PLT Angin di Desa Wukirsari diperlukan studi kelayakan agar terbangun PLT Angin yang sustainable. Hal tersebut penting mengingat Indonesia terletak di daerah rawan gempa dan tsunami dan penduduk yang padat.

Analisis potensi merupakan salah satu studi pra kelayakan pembangunan PLT Angin. Untuk membangun PLT Angin di Desa Wukirsari sebagai sumber ketenagaan SPAM diperlukan studi pra kelayakan yang lebih lengkap, yaitu studi mengenai masalah sosial, lingkungan, dan ekonomi agar tercapai sustainable building.

\section{DAFTAR PUSTAKA}

Andhy Muhammad Fathoni. Perancangan dan Analisa Ekonomi Solar Pumping System di Sumber Air Kaligede. Skripsi, Jurusan Teknik Fisika, Fakultas Teknik, Universitas Gadjah Mada, 2008.

Anonim. Dari Aspek Transfer Teknologi, Kelembagaan, dan Partisipasi Masyarakat 


\section{DHANIS WORO FITTRIN SELO NUR GIYATNO ANALISIS POTENSI ENERGI DI DESA WUKIRSARI, KECAMATAN IMOGIRI, KABUPATEN BANTUL, PROPINSI ...}

Mei 2009. www.gtz.de Indonesia.

Anonim. Kecamatan Imogiri. Diakses dari www.googlemaps.com, 26 Mei 2010.

Atmospheric Science Data Center. Surface meteorology and Solar Energy. Diakses dari http:/ / eosweb.larc.nasa.gov/ sse/, 17 Mei 2010.

Departemen Pekerjaan Umum. Undangundang Republik Indonesia Nomor 26 Tahun 2007 tentang Penataan Ruang. Departemen Pekerjaan Umum, Jakarta, 2007.

Departemen Pekerjaan Umum. Peraturan Menteri Pekerjaan Umum No. 06/ PRT/M/2009 tentang Pedoman Perencanaan Umum Pembangunan Infrastruktur di Kawasan Rawan Tsunami. Kementrian Pekerjaan Umum, Jakarta, 2009.

Deputi Bidang Tata Lingkungan. Memprakirakan Dampak Lingkungan Kualitas Udara. Kementrian Negara Lingkungan Hidup, Jakarta, 2007.

Dewan Redaksi. Indikator Pembangunan Berkelanjutan di Indonesia. Diakses dari http://bulletin.penataanruang. net/upload/data_artikel/data $\% 20$ bltn\%202009.pdf, 10 Juli 2010.

Dhanis Woro Fittrin Selo Nur Giyatno. Perancangan dan Studi Kelayakan Sistem Penyediaan Air Minum (SPAM) (Studi Kasus: Desa Wukirsari, Kecamatan Imogiri, Kabupaten Bantul, Provinsi Daerah Istimewa Yogyakarta). Skripsi, Jurusan Teknik Fisika, Fakultas Teknik, Universitas Gadjah Mada, 2010.

Dinas Sosial Kabupaten Bantul. Jumlah Penerima Blt Tahun 2009 Kabupaten Bantul. Diakses dari http://sosial. bantulkab.go.id/index/20, 17 Juli 2010.

Djati H. Salimy, Ida N., Finahari, Elok S., Amitayani. Analisis Biaya Eksternal
PLTU Batubara. Diakses dari http:// jurnal.sttn-batan.ac.id/wp-content/ uploads/2010/03/C-18.pdf, 10 Juli 2010.

Felix A. Farret and M. Godoy Simoes. Integrating o Alternative Sources of Energy. John Wiley \& Sons, Inc., New Jersey, 2002.

Maria Retnanestri. Improving Sustainability of Energy Service Delivery in Rural Indonesia Using the I3A Framework. Diakses dari http://www. ceem.unsw.edu.au/content/ RenewableEnergy Indonesia. cfm?ss=1, 6 November 2009.

Menteri Pekerjaan Umum. Peraturan Pemerintah Republik Indonesia Nomor : 18/PRT/M/2007 tentang Penyelenggaraan Pengembangan Sistem Penyediaan Air Minum. Departemen Pekerjaan Umum, Jakarta, 2007.

Nassir El Bassam dan Preben Maegaard. Integrated Renewable Energy for Rural Communities. Elsevier, Amsterdam, 2004.

Pemerintah Republik Indonesia. Peraturan Pemerintah Republik Indonesia Nomor 16 Tahun 2005 tentang Pengembangan Sistem Penyediaan Air Minum. Diakses dari http://www.bpkp.go.id/unit/ hukum/pp/2005/016-05.pdf, 9 Maret 2010

Presiden Republik Indonesia. Lampiran Peraturan Presiden Republik Indonesia Nomor 5 Tahun 2010 tentang Rencana Pembangunan Jangka Menengah Nasional (RPJMN) Tahun 20102014. Kementrian Perencanaan Pembangunan Nasional/Badan Perencanaan Pembangunan Nasional (BAPPENAS), Jakarta, 2010.

Supriyono dan Subejo. Harmonisasi Pemberdayaan Masyarakat Pedesaan dengan Pembangunan Berkelanjutan. Diakses dari http://subejo.staff. ugm.ac.id/wp-content/supriyantoekstensia.pdf, 16 Maret 2010. 


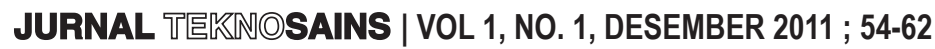

Tony Buston, David Sharpe, Nick Jenkins, Yulesta Putra. Perencanaan Dengan Konsep and Ervin Bosannyi. Wind Energy Handbook. John Willey \& Sons, Sustainable Building (Faktor Penting Chinchester, 2002.

dalam Penerapan Sustainable

Development). Repositori, Program Studi Arsitektur, Fakultas Teknik, Universitas Sumatra Utara, 2004. 